\title{
Guidance-Counselling Strategies and Conformity with Code of Conduct in Secondary Schools in Gulu Municipality, Uganda
}

\author{
Grace Kasigwa Mbabazi ${ }^{1}$ \& Jerry Bagaya, ${ }^{2, *}$ \\ ${ }^{1}$ Faculty of Education and Humanities, Gulu University, Gulu, Uganda, East Africa \\ ${ }^{2}$ Kyambogo University Graduate School, Kampala, Uganda, East Africa \\ *Corresponding author: Kyambogo University Graduate School, P.O Box 1, Kampala, \\ Uganda, East Africa Tel: 256-772-959-140Ｅ-mail: jbagaya@yahoo.co.uk
}

Received: February 3, 2013

Accepted: March 22, 2013 Published: April 30, 2013

doi:10.5296/ije.v5i2.3211

URL: http://dx.doi.org/10.5296/ije.v5i2.3211

\begin{abstract}
The purpose of this research paper is to demonstrate that guidance and counselling strategies play a central role in school efforts to improve learners' levels of conformity with the code of conduct. A cross sectional parallel sample survey design was used. A total of 366 respondents comprising of 226 teachers and 140 prefects, in secondary schools in Gulu Municipality, selected through simple random and expert sampling were studied. Two pre-tested and validated questionnaires were used to collect the data. Three hypotheses were formulated to guide the study and were tested using descriptive statistics and Chi square tests. The study revealed that individual guidance and counselling strategy was commonly used and that learners' level of conformity with the code of conduct is moderate. The results further revealed that learners' level of conformity with the code of conduct does not significantly depend on the guidance and counselling strategy used. Based on these findings, the researchers recommend that school administrators should adopt the use of both individual and group counselling strategies and that Ministry of Education and Sports (MoES) should conduct in-service training for all teachers on techniques of guidance and counselling. The study proposes areas for further research including investigating the effectiveness of guidance and counselling services, and the moderating effects of sex, qualification, experience, and school resources on the relationship between the variables.
\end{abstract}

Keywords: guidance; counselling; code of conduct; teachers; prefects; Gulu; Uganda 


\section{Introduction}

\subsection{Background}

For any school to achieve its goals, order must be maintained. Maintenance of order however, requires that boundaries of behaviour be set (Skiba \& Peterson, 2000) in a code of conduct and communicated to all (Bakhda, 2004). Not all learners, however, adhere to the school code of conduct, and require guidance and counselling services.

The terms guidance and counselling are like two sides of the same coin though there has been a tendency to use them interchangeably. Guidance is the process of assisting learners to recognise their potential to work though problems (Chireshe, 2006; Lunenburg, 2010; MoES, 2004; Mutei \& Ndabuki, 1999). Counselling, on the other hand, has been defined as the process of helping an individual to explore difficulties experienced in life so as to make informed decisions that will lead towards more satisfying life (Chireshe, 2006; Lunenburg, 2010; Idowu, 2008; Otyek, 1993). These definitions imply that counselling is an integral part of guidance without which guidance can never be complete.

From the aforementioned definitions, guidance and counselling strategies were considered as modes of conducting guidance and counselling sessions. These modes were categorised as individual guidance and counselling that deals with one learner and group guidance and counselling that deals with more than one learner at a time. The strategies aim at ensuring that learner behaviour, character, attitudes, values and life circumstances improve. Group guidance and counselling allows common problems to be handled at once and provides a safe environment for learners to express their feelings concerns and experiences (Directorate of Education Standards [DES], 2008b; Hayes, 2001; Lunenburg, 2010; Otyek, 1993; Weller, 2000). This strategy, however, suffers from lack of privacy and confidentiality (Aleck, 2003; Okiror, 2009). Individual guidance and counselling comes in handy to address these challenges. It focuses on deeper understanding of the learner as an individual and establishes self concept and sound identity (Lam, 2000; Chireshe, 2006). The challenge here is that since individual guidance and counselling is learner-initiated, learners may not easily confide in the teachers and may end up not being helped out of their difficulties (Mutei \& Ndambuki, 1999), resulting in not complying with the code of conduct.

A code of conduct provides a framework of what is considered to be appropriate standards of learner behaviour (Hornby, 2001; Muhiire, 2002; Yarason \& Zaria, 2004) while undertaking academic and non-academic activities (Bakhda, 2004). In this study, conformity with the code of conduct was taken to be the level at which learners comply with standards that regulate behaviour-conceptualised at five levels (very low, low, moderate, high \& very high).

No studies have directly linked guidance and counselling strategies to conformity with the school code of conduct. Research literature, however, has indicated a link between guidance and counselling services and discipline. For example, Simatwa (2012) attributed the high levels of student unrest in Kenyan secondary schools to ineffective guidance and counselling services among other reasons. The study revealed that $50 \%$ and $25 \%$ of the prefects and teachers respectively considered guidance and counselling services as a waste of time and 
only meant for learners with mental illness. A 2010 study by Ajowi and Simatwa found similar findings. They reported numerous incidents of disciplinary problems in Kisumu District, Kenya and posited that the major contributing factor was lack of effective proactive measures such as guidance and counselling. Another study in secondary schools in Benin City, Nigeria found a significant relationship $(r=0.524)$ between guidance and counselling services and learners' adjustment. These findings support the results by Lam (2000), Imich (1996), Kochhar (1970), Muhiire (2002) who asserted that learners did not behave according to accepted standards because of lack of appropriate guidance. While these studies reveal relationship between guidance and counselling services and learner discipline, none has considered one key aspect of the study, guidance and counselling strategies. Similarly, all the studies have not indicated the levels of student discipline. This study was more interested in establishing the relationship between guidance and counselling strategies and learners' level of conformity to the code of conduct.

\subsection{Statement of the Problem}

The MoES has put in place measures to strengthen guidance and counselling services in education institutions in Uganda. It has, for example, created a fully fledged Department of Guidance and Counselling in MoES, developed reference materials for teachers, conducted workshops, strengthened monitoring and supervision, and developed policies and guidelines to address psychosocial difficulties experienced by school children ( MoES, 2010; Ssenkuma, 2010). Despite these efforts, there has been an escalation of indiscipline among secondary school students in Uganda, Gulu Municipality inclusive. Literature is awash with reports on strikes, student unrest, examination malpractices, absenteeism, drug abuse and bullying (DES, 2008a, 2009; Ocoromach, 1999; Seburimage, 1998; Uganda National Examinations Board [UNEB], 2005, 2006). According to DES (2008a) and MoES (2008), one of the reasons for this trend of events is that learners' needs are not attended to in time. It is pertinent to ask: To what extent are guidance and counselling services used to align student behaviour to the code of conduct. The problem of this study, therefore, was to investigate whether the apparent learners' level of conformity with the code of conduct is due to guidance and counselling strategies used.

\subsection{Purpose of the Study}

The purpose of the study was to establish whether there is a relationship between guidance and counselling strategies and learners' level of conformity with the code of conduct in secondary schools in Gulu municipality.

\subsection{Objectives of the Study}

1) To find out the guidance and counselling strategies used in secondary schools in Gulu Municipality.

2) To establish learners' level of conformity with the code of conduct in secondary schools in Gulu Municipality.

3) To determine the degree of relationship between guidance and counselling strategies and 
learners' level of conformity with the code of conduct.

\subsection{Hypotheses}

Based on the purpose and objectives of the study, three null hypotheses were formulated.

1) There is no significant difference in guidance and counselling strategies used in secondary schools in Gulu Municipality.

2) There is no significant difference in learners' level of conformity with the code of conduct in secondary schools in Gulu Municipality.

3) There is no statistically significant relationship between guidance-counselling strategies and learners' level of conformity with the code of conduct.

\subsection{The Scope of the Study}

The study was carried out in Gulu Municipality, Gulu District, Uganda. Gulu Municipality has four divisions: Bardege, Layibi, Laroo and Pece, all of which formed the study area. The subject matter scope was limited to two strategies of guidance and counselling (Individual \& Group) and two dimensions of the code of conduct (Academic \& Non-academic). The study was limited by participation to prefects and teachers who are concerned with guidance and counselling services and ensuring that learners conform to the code of conduct.

\subsection{Significance of the Study}

Guidance and counselling is an important tool for achieving discipline through which school aims and objectives are attained. Effective guidance and counselling leads to improved academic performance, builds self confidence and total development of learners. The results from the study will help school administrators to re-examine their approach to guidance and counselling services. In addition, it will remind the MoES on its responsibility to support guidance and counselling services in secondary schools. It will also contribute to the body of knowledge and reveal gaps for further research in the field of guidance and counselling and discipline management in educational institutions.

\subsection{Conceptual Framework}

The model in Figure 1, on which this study is based, examines the interrelationships between guidance and counselling strategies and level of conformity with the code of conduct in two dimensions namely academic and non-academic. 


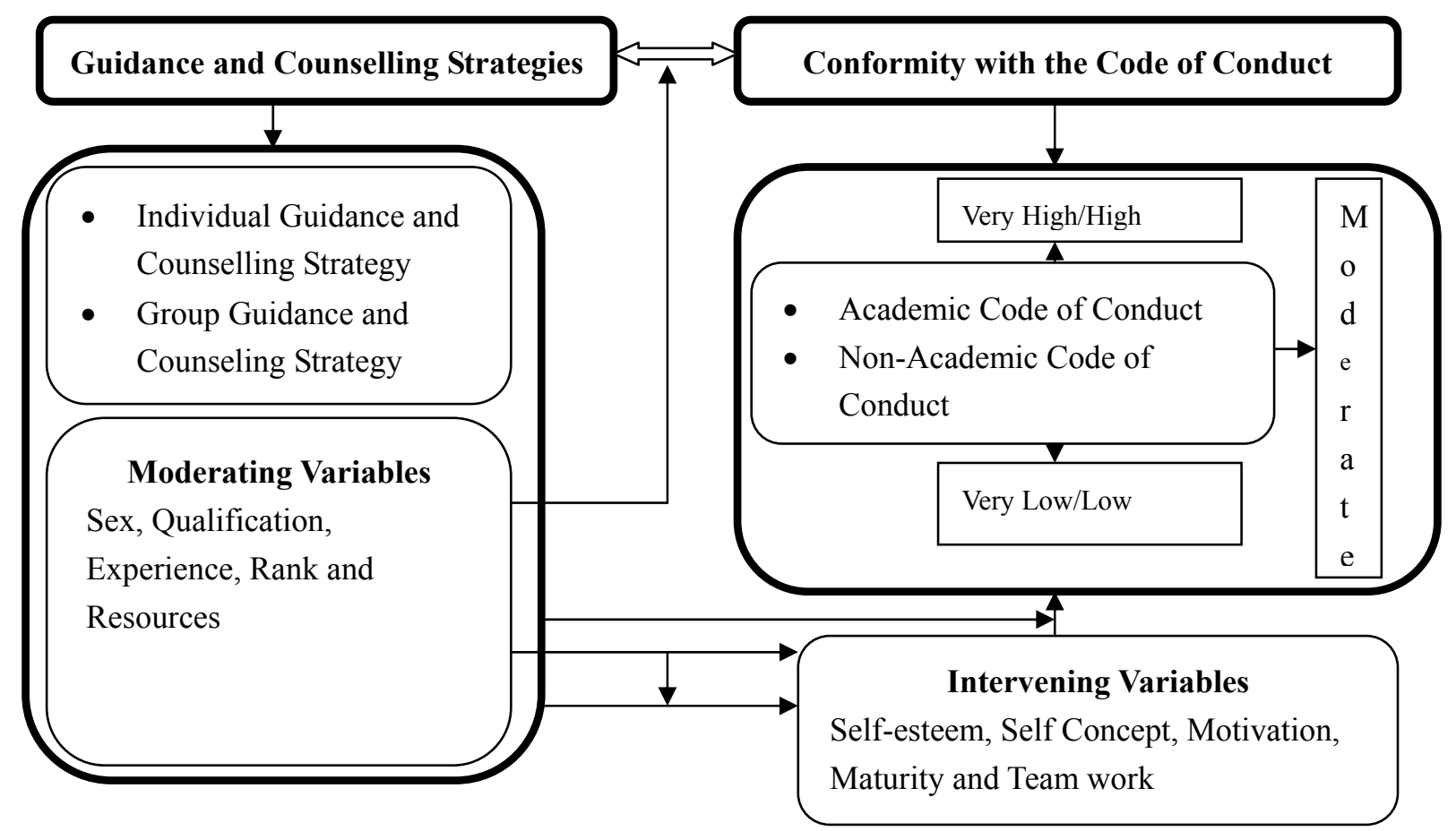

Figure 1: Conceptual Framework for the Study Variables

The model illustrates that guidance and counselling strategies categorised as individual and group, can be used to shape learner behaviour in a way of conforming to the code of conduct in two dimensions namely academic and non-academic. Also important in the model is the recognition of the presence of extraneous variables (moderating and intervening). This study, however, was interested in studying whether the guidance and counselling strategy used is a precondition for conformity to the code of conduct.

\section{Methodology}

\subsection{Research Design}

The study used a cross sectional parallel sample survey design to collect information from different categories of respondents at a given point in time. The target population of the study consisted of 550 teachers and 220 prefects for the classes S.3 to S.4. The unit of analysis was an individual respondent. Using the Krejcie and Morgan Table (Amin, 2005), a sample size of 226 teachers and 140 prefects was obtained. Simple random sampling was used to select the schools and the prefects while expert sampling was used to select the teachers ensuring that those in-charges of guidance and counselling were included. As a result the greatest possible accuracy of data was ensured (Sidhu, 2001; Singh, 2007).

\subsection{Instrumentation}

The researchers used questionnaires to enable the collection of data from a large and literate sample (Bagaya, Odiya \& Mbabazi, 2012). The Guidance and counselling strategies scale (GCSS) consisted of 26 close-ended items with each being dichotomously scored. For example; 
the first item on GCSS was: When being advised on HIV/ AIDS and sexually transmitted disease, students are advised in: (a) Groups (b) Individually. The second instrument, the conformity to code of conduct scale (CCCS), had 24 close-ended items requiring respondents to agree at five levels (strongly agree, agree, neutral, disagree, \& strongly disagree). For example, the first item on CCCS required respondents' level of agreement with the statement 'Student attend all lessons as indicated on the school timetable'.

The initial instruments were pre-tested with a convenient sample of 20 respondents in secondary schools in Gulu Municipality that did not form part of the study. For the GCSS and CCCS, a Kuder Richardson-20 reliability coefficient of 0.81 and a Cronbach's alpha of 0.89 respectively where obtained. These were above the minimum acceptable value $(0.70)$ for research (Amin, 2005, p.302; Wiersma \& Jurs, 2005, p.327). To test for validity, analysis of judgements of three specialists on the relevance of the items to the study purpose gave content validity indices of 0.76 and 1.00 for GCSS and CCCS respectively. Some items were modified as suggested by the experts.

The questionnaires were administered by research assistants to teachers and prefects while the researchers administered the questionnaires to teachers in-charge of guidance and counselling and prefects in-charge of discipline. The quality of the data was ensured through thorough training of research assistants, contacting respondents before the date of the fieldwork, spot checking of completed questionnaires to ensure that all items were responded to, and supervision and monitoring of the data collection process. Subsequently, a unit response rate of $87.4 \%$ was realised.

\subsection{Data Analysis}

Data from the GCSS was summed for each respondent to determine the perception as to whether the guidance and counselling was group or individual. The summated scores ranged from 26 to 52. Consequently, guidance and counselling strategies were coded as 1 for individual guidance and counselling $(26-<40)$ and 2 for group guidance and counselling (40 52). For the CCCS, the summated scores ranged from 24 to 120 . The resulting summated score ratings were coded as follows: 1 for very low $(24-<42), 2$ for low $(42-<62), 3$ for moderate $(62-<82), 4$ for high $(82-<102)$, and 5 for very high $(102-120)$. SPSS Version 17.0 was used to analyse the data. Hypotheses 1 and 2 that concern differences were analysed using the Chi square test of goodness of fit. Hypothesis 3 that concerns association between categorical variables was analysed using the Chi square test of independence. All the hypotheses were tested at a 5\% level of significance (Amin, 2005; Bagaya, Odiya \& Mbabazi, 2012; Balnaves \& Caputi, 2001; Singh, 2007).

\section{Results}

\subsection{Hypothesis 1}

The first hypothesis was stated as: There is no significant difference in the guidance and counselling strategies used in secondary schools in Gulu Municipality. This non-directional 
hypothesis was tested at a $5 \%$ level of significance.

Table 1: Descriptive statistics on perceptions of guidance and counselling strategies

\begin{tabular}{llcl}
\hline & \multicolumn{3}{l}{ Guidance and Counselling Strategies } \\
\cline { 2 - 4 } Frequency & Individual & Group & Total \\
\hline Observed & $231(70)^{*}$ & $99(30)$ & 330 \\
Expected & $165(50)$ & $165(50)$ & 330 \\
\hline
\end{tabular}

*Figures in brackets represent row percentages

The descriptive statistics in row 3 of Table 1 indicate that the majority of the respondents $(70 \%)$ reported individual guidance and counselling was used as opposed to only $30 \%$ reporting the use of group guidance and counselling. These statistics suggest that there are differences in respondents perceptions of guidance and counselling strategies used in the sampled schools.

The Chi square test of goodness of fit was used since the hypothesis involves one categorical variable, no cell has zero expected frequency, and $0 \%$ of the expected frequencies had counts less than five (Row 4 of Table 1). The results of the Chi square test of goodness of fit, $X^{2}(1$, $n=330)=52.800, p<0.001$, indicates that there is a statistically significant difference in guidance and counselling strategies. Consequently, Hypothesis 1 is rejected.

\subsection{Hypothesis 2}

The second hypothesis was stated as: There is no significant difference in learners' level of conformity with the code of conduct in secondary schools in Gulu Municipality.

Table 2: Descriptive statistics on perceptions of conformity to the code of conduct

\begin{tabular}{lclllll}
\hline & \multicolumn{2}{l}{ Level of Conformity to Code of Conduct } & & \\
\cline { 2 - 7 } Frequency & Very Low & Low & Moderate & High & Very High & Total \\
\hline Observed & $8(2.4)^{*}$ & $18(5.5)$ & $116(35.2)$ & $122(37.0)$ & $66(20.0)$ & 330 \\
Expected & $66(20.0)$ & $66(20.0)$ & $66(20.0)$ & $66(20.0)$ & $66(20.0)$ & 330 \\
\hline
\end{tabular}

*Figures in brackets represent row percentages

This two-tailed hypothesis was tested at a $5 \%$ level of significance.

The descriptive statistics in Row 3 of Table 2 indicate that the majority of respondents $(57 \%)$ perceived the level of conformity with the code of conduct to be at least high, only $7.9 \%$ considered it to be at most low and $35.2 \%$ considered it as moderate. This suggests that there are differences in learners' level of conformity with the code of conduct in the sampled schools.

Since the hypothesis involves one categorical variable, no cell has zero expected frequency and $0 \%$ of the cells have expected frequencies less than five (Row 4 of Table 2), the Chi square test of goodness of fit was used to analyse the data. The results of the Chi square test of goodness of fit, $X^{2}(4, n=330)=171.273, p<0.001$, indicate that there is a statistically significant difference in learners' level of conformity with the code of conduct. We can, 
therefore, reject the null hypothesis and conclude that there is a statistically significant difference in the level of conformity with the code of conduct; with more learners $(37 \%)$ having high level compared to few learners $(2.4 \%)$ with very low level of conformity.

\subsection{Hypothesis 3}

This was stated as: There is no statistically significant relationship between guidance and counselling strategies and learners' level of conformity with the code of conduct. This non-directional hypothesis was tested at a $5 \%$ level of significance.

Table 3: Descriptive statistics for the relationship between the study variables

\begin{tabular}{|c|c|c|c|c|c|c|c|}
\hline \multirow{3}{*}{\multicolumn{2}{|c|}{$\begin{array}{l}\text { Guidance and } \\
\text { Counselling Strategies }\end{array}$}} & \multicolumn{6}{|c|}{ Level of Conformity with the Code of Conduct } \\
\hline & & \multirow{2}{*}{$\begin{array}{l}\text { Very } \\
\text { Low }\end{array}$} & \multirow[t]{2}{*}{ Low } & \multirow[t]{2}{*}{ Moderate } & \multirow[t]{2}{*}{ High } & \multirow[t]{2}{*}{ Very High } & \multirow[t]{2}{*}{ Total } \\
\hline & & & & & & & \\
\hline \multirow[t]{2}{*}{ Individual } & Frequency & $3(5.6)^{*}$ & $9(12.6)$ & $80(81.2)$ & $92(85.4)$ & $47(46.2)$ & 231 \\
\hline & Column \% & 37.5 & 50.0 & 69.0 & 75.4 & 71.2 & 70.0 \\
\hline \multirow[t]{2}{*}{ Group } & Frequency & $5(2.4)$ & $9(5.4)$ & $36(34.8)$ & $30(36.6)$ & $19(19.8)$ & 99 \\
\hline & Column $\%$ & 62.5 & 50.0 & 31.0 & 24.6 & 28.8 & 30.0 \\
\hline $\begin{array}{l}\text { Total } \\
\text { Frequency }\end{array}$ & & 8 & 18 & 116 & 122 & 66 & 330 \\
\hline
\end{tabular}

*Values in brackets represent expected frequencies

The study's descriptive statistics in Row 4, Column 6 and Row 6, Column 3 of Table 3 indicate that for individual guidance and counselling strategy, majority of learners $(75.4 \%)$ were perceived to have high level of conformity with the code of conduct. Conversely, majority of learners $(62.5 \%)$ were perceived to have very low level of conformity to the code of conduct when group guidance and counselling was predominant. This suggests that the more individual guidance and counselling is used, the higher the level of conformity with the code of conduct. Conversely, the more group guidance and counselling is used, the lower the level of conformity with the code of conduct.

Since the data for testing Hypothesis 3 involved establishing relationship between categorical variables, the most appropriate non-parametric test was the Chi square test of independence. Furthermore the data showed no violation of the basic assumptions for the application of the Chi square test as no cell had zero expected frequency (Rows $3 \& 5$ of Table 3 ) and only one cell $(10 \%)$ had expected frequency less than five ( Row 5, Column 3 of Table 3 ).

The Chi square test of independence was performed to examine the relationship between guidance and counselling strategies and learners' level of conformity with the code of conduct. The relationship between the variables was not significant, $\mathcal{X}^{2}(4, n=330)=9.258$, $p=0.55$. There is, therefore, no statistically significant relationship between guidance and counselling strategies and learners' level of conformity with the code of conduct in the population from which the sample of 366 respondents was drawn. 


\section{Discussions}

The results of the study on 366 teachers and prefects of secondary schools in Gulu Municipality were presented in the previous section. In this section, the results are discussed while conclusions drawn and recommendations made in the proceeding sections.

The first finding of the study was that there is a statistically significant difference in guidance and counselling strategies used. Respondents were of the view that individual guidance and counselling strategy was commonly used as opposed to group guidance and counselling. This finding is consistent with the findings of Ajowii and Simatwa (2010), Egbochuku (2008), and Simatwa (2012) that guidance and counselling services tended to be provided to individuals after administering punishment and meant for those who could not solve their own problems. As such only a small number of learners were likely to turn up for guidance and counselling services. Given that the majority of schools in the sample relied on individual guidance and counselling, a question is raised on the effectiveness of such services in-terms of reaching out to all learners and variation in strategy depending on the needs to be addressed. The findings, however, are at variance with those by Chireshe (2006) and DES (2008b) that reveal predominant use of group guidance and counselling strategy. These studies were carried out in Zimbabwe and Manafwa district, Uganda respectively that have experienced relative peace over the years. This study was carried out in Gulu Municipality where majority of learners suffer from post traumatic stress as a result of the 20-year insurgency and schools may prefer to deal with learners on individual basis.

The second finding of the study revealed a statistically significant difference in the level of conformity with the code of conduct. The majority of learners were rated as moderate. The finding of this study tends towards agreement with the results of Day and Golench (1997), Imich (1996), Morrison (2003), Muhiire (2002), Seburimage (1998), Simatwa (2012), Ocoromach (1999), and Yarason and Zaria (2004) that revealed low levels of conformity with the code of conduct. Given that the region was still recovering from the 20 -year insurgency that has left many adolescent learners and teachers traumatised, the likelihood of learner misbehaviour is high if their needs are not identified and addressed (DES, 2008a; World Vision, 2004). As such they are more likely to be rated below the minimum acceptable level of conformity with the code of conduct. In addition most of the infrastructure in the schools does not allow for effective guidance and counselling services. The biggest challenge in secondary schools, with the introduction of Universal Secondary Education (USE), is high student-teacher ratio as a result of increasing enrolment without an equivalent increase in the staff (Bagaya, 2012). The slight deviation from the findings of the reviewed literature, however, can be explained in terms of biasness in self reporting and general thinking that the learners in the Municipality were trying to cope with the situation. There is a likelihood of bias in self reporting about ones activities resulting in a tendency for people to rate themselves favourably. Since the majority of respondents were learners, the overall rating of the level of conformity with the code of conduct as moderate was inevitable. Teachers, on the other hand, tend to rate their students favourably as an indication that they are effectively carrying out their duties. 
The third finding revealed that there is no statistically significant relationship between guidance and counselling strategies and learners' level of conformity with the code of conduct. The more one strategy is used at the expense of the other, the lower the level of conformity with the code of conduct. Although there is limited research directly linking guidance and counselling strategies to conformity with the code of conduct, the findings of this study are in tandem with the available literature. Chireshe's (2006) and United Nations Educational, Scientific and Cultural Organisation's [UNESCO's] (1982) findings are supported by the findings of this study. These findings can be explained by the fact that each guidance and counselling strategy is effective in handling specific situations and that not all situations can be dealt with using only one strategy. Group guidance and counselling is more effective in handling problems common to all learners (Hayes, 2001; UNESCO, 1982). Such problems include: Orientating new comers, choice of schools/subjects/courses, examination techniques, and revision skills. In a group set up, a conducive environment is tenable for learners to express their concerns and receive feedback that helps them live better lives.

Individual guidance and counselling, on the other hand, is more effective in handling personal challenges such as coping with stress, loss of relative, subject difficulty, and other family related issues. In such situations, learners cannot easily open up to a group for fear of being exposed. For example, whereas learners with high self esteem would feel comfortable to air out their challenges in a group setting, timid and shy learners will not. Over use of one strategy, therefore, means that other aspects of guidance and counselling are neglected and likely to contribute to learner misbehaviour. Both individual and group guidance and counselling strategies augment each other and should be used depending on the situation that unfolds.

\section{Conclusions}

The researchers intended to explore the relationship between guidance and counselling strategies and level of conformity with the code of conduct. A cross sectional parallel sample survey design with a sample of 366 teachers and prefects in secondary schools in Gulu Municipality was used. Questionnaire data was analysed using the Chi square test. The analysis revealed a statistically significant difference in guidance and counselling strategies, a statistically significant difference in levels of conformity with the code of conduct, and no statistically significant relationship between guidance and counselling strategies and learners' level of conformity with the code of conduct. In view of these findings, the study concludes that individual guidance and counselling strategy is commonly used in secondary schools in Gulu Municipality, learners' level of conformity with the code of conduct is moderate, and that learners' level of conformity with the code of conduct does not significantly depend on guidance and counselling strategy used.

\section{Recommendations}

Based on the findings and conclusions of this study, the following recommendations for 
practice as provided.

1) Headteachers and teachers should adopt the use of both group and individual guidance and counselling.

2) The MoES should organise in-service training on school guidance and counselling for all teachers and headteachers.

Since our study was limited to the relationship between guidance and counselling strategies and level of conformity with the code of conduct in secondary schools in Gulu Municipality, further research should investigate into the following.

1) The effectiveness of guidance and counselling strategies in secondary schools.

2) The moderating effects of teacher's sex, qualification, experience, rank and school resources on the relationship between the variables of the study.

3) Replication of the study to primary schools and tertiary institutions.

\section{References}

Ajowi, J.O., \& Simatwa, E.M.W. (2010). The role of guidance and counselling in promoting student discipline in secondary schools in Kenya: A case study of Kisumu district. Education Research and Reviews, 5(5), 263-272.

Aleck, W. A. (2003). Guidance: A new dimension of creative teaching. In C. C. Skinner (Ed.), Educational Psychology (pp. 44-71). New Delhi: Prentice hall.

Amin, E. M. (2005). Social science research conception, methodology and analysis. Kampala: Makerere University Printery.

Bagaya, J. (2012). Report on inspection of secondary schools in Gulu and Nwoya districts. Kampala: DES.

Bagaya, J., Odiya, J.N., \& Mbabazi, K.G. (2012). Supervision practices and human resource management efficiency in Gulu district primary schools, Uganda: A survey based investigation. International Journal of Current Research, 4(7), 57-65.

Bakhda, S. (2004). Management and evaluation of schools. Nairobi: Oxford University Press.

Balnaves, M., \& Caputi, P. (2001). Introduction to quantitative research methods. London: Sage.

Chireshe, R. (2006). An assessment of the effectiveness of school guidance and counselling services in Zimbabwean secondary schools. Unpublished Doctor of Education Dissertation. University of South Africa, Johannesburg.

Day, M. D., \& Golench A.C. (1997). Promoting safe schools through policy results of a survey of Canadian school boards. Journal of Education Administration, 35, 332-347. http://dx.doi.org/10.1108/09578239710171929 
Directorate of Education Standards. (2008a). An investigation into the student unrest at St. Joseph's college Layibi, Gulu Municipality. Gulu: Author.

Directorate of Education Standards. (2008b). A report on the inspection of education institutions in Manafwa district. Kampala: Author.

Directorate of Education Standards. (2009). Monitoring report on the beginning of term I, 2009 in secondary schools in Masindi district. Kampala: Author.

Egbochuku, E.O. (2008). Assessment of the quality of guidance and counselling services to students' adjustment in secondary schools in Edo State of Nigeria. Research Journal of International Studies, 8, $42-50$.

Hayes, G.B (2001). Group counselling in schools: Effective or not? International Journal of Sociology and Social policy, 21, 12-20. http://dx.doi.org/10.1108/01443330110789321

Hornby, (2001). Oxford advanced learners dictionary $\left(6^{\text {th }}\right.$ ed). Oxford: Oxford University Press.

Idowu, S. (2007). Guidance and counselling for primary school children. Author.

Igule, F., \& Gatumu, H. (1996). Essentials of educational statistics. Nairobi; Kampala: East African Educational Publishers.

Imich, A. (1996). Exclusions from schools. Health Education, 4, 28-31. http://dx.doi.org/10.1108/09654289610119036

Kochhar, S. K. (1970). Guidance and counselling in colleges and Universities. New Delhi: Sterling.

Lam, Y.L.J. (2000). Re-conceptualising problem solving and conflict resolution in schools: A multi-disciplinary perspective. The International Journal of Education Management, 14, 84-89. http://dx.doi.org/10.1108/09513540010315904

Lunenburg, F.C. (2010). School guidance and counselling services. Schooling, 1(1), 1 - 9.

Ministry of Education \& Sports. (2004). Presidential initiative on AIDS strategy for communication to youth: Helping pupils stay safe. Kampala: Entebbe Government Printers.

Ministry of Education \& Sports. (2008). An introductory handbook for promoting positive discipline in schools for quality education: Alternatives to corporal punishments. Kampala: Entebbe Government Printers.

Ministry of Education and Sports. (2010). Guidance and counselling strategies and plans. Journal of Guidance and Counselling, 1(1), 2-3.

Morrison, E. B. (2003). Regulating safe school communities: Being responsive and restorative. Journal of Education Administration, 41, 689-704. http://dx.doi.org/10.1108/09578230310504661 
Muhiire, L. J. (2002). Management and control of students' behaviour at Makerere University. An unpublished Master of Arts (Education Management) dissertation, Makerere University, Kampala.

Mutei, E. K., \& Ndambuki, P. (1999). Guidance and counselling for schools and colleges. Nairobi: Oxford University Press.

Ocoromach, O. H. (1999). Teachers' perceptions and strategies of enforcing discipline in Ugandan rural and urban secondary schools. An unpublished Master of Education (guidance and counselling) dissertation, Makerere University, Kampala.

Okiror, D. (2009, March 28). The trials of a virgin groom. The New vision, 3, 26.

Otyek, C. M. (1993). The basics of guidance and counselling for secondary schools and teachers. Kampala: Author

Seburimage, D. M. (1998). Students'discipline and academic performance. An Un published Master of Education dissertation, Makerere University, Kampala.

Sidhu, K.S. (2001). Methodology of Research in Education. New Delhi: Sterling Publishers. Private Limited.

Simatwa, E.M.W. (2012). Management of student discipline in secondary schools in Kenya: A case study of Bungoma County. Education Research, 3(2), 172-189.

Singh, K. (2007). Quantitative social research methods. New Delhi: Sage.

Skiba, R., \& Peterson, R. (2000). The Dark side of zero tolerance: Can punishments lead to safe schools? In F. Schultz (Ed.), Education (pp. 118-125).

Ssenkumba, M. (2010). School based peace education and guidance and counselling in secondary schools in Northern Uganda. Kampala: SPRING.

Uganda National Examination Board. (2005). Duties of officers deployed on UCE monitoring. Kampala: Author.

Uganda National Examination Board. (2006). Duties of officers deployed on UCE monitoring. Kampala: Author

United Nations Educational Scientific \& Cultural Organisation. (1982). Educational and vocational guidance in secondary school in Kuwait. Paris: Author.

Weller, D. L (2000). School attendance problems: Using the TQM tools to identify root causes. Journal of Educational Administration, 38, 64-82. http://dx.doi.org/10.1108/09578230010310984

Wiersma, W., \& Jurs, S. G. (2005). Research methods in education: An introduction ( $8^{\text {th }}$ ed.). Boston: Allyn \& Bacon.

World Vision. (2004). Pawns of politics children, conflict and peace in northern Uganda. Kampala: Author 
Yahaya, L. A.(2006). Guidance and uses of tests in primary schools. Retrieved June15, 2009, from http// www.kwsubeb.com

Yarason, M.C., \& Zaria,C. E.F.P. (2004). Strategies for curbing indiscipline in Nigerian secondary schools. Retrieved March 1, 2009 from http// www.accs.org.uk

\section{Copyright Disclaimer}

Copyright reserved by the author(s).

This article is an open-access article distributed under the terms and conditions of the Creative Commons Attribution license (http://creativecommons.org/licenses/by/3.0/). 